\title{
FREQUENTLY USED ABBREVIATIONS
}

ADATAM-Association de défense des anciens travailleurs au Maroc (Association for the Defense of Former Workers of Morocco)

AFASPA-Association Française d'Amitié et de Solidarité avec les Peuples d'Afrique (French Association for Friendship and Solidarity with the People of Africa)

AFSC-American Friends Service Committee

AG-Association Générale (General Association), est. I919

AIU-Alliance Israélite Universelle (Universal Israelite Alliance), est. I860

ALN-Armée de Libération Nationale (National Liberation Army)

BAHAD - Brith Halutzim Datiyim (Alliance of Religious Pioneers)

CAM-Comité d'Action Marocaine (Moroccan Action Committee)

CCIM-Conseil des Communautés Israélites du Maroc (Council of Jewish Communities of Morocco)

CGQI-Commisariat Général aux Questions Juives (General Commissariat for Jewish Questions), est. 1940

CGT-Confédération Générale du Travail (General Confederation of Labor)

FDIC-Front pour la Défense des Institutions Constitutionelles (Front for the Defense of Constitutional Institutions), est. 1963 
FLN—Front de Libération Nationale (National Liberation Front)

HIAS-Hebrew Immigrant Aid Society, est. I88I

JDC—Joint Distribution Committee, est. I9I4

LDH—Ligue des droits de l'homme (League for Human Rights)

LICA—Ligue international contre l'antisémitisme (International League Against Anti-Semitism), est. 1928

MENA-Middle East and North Africa

OCP-Office Chérifien des Phosphates (Sharifian Office of Phosphates), est. 1920

ORT-Organisation Reconstruction Travail (the most common English translation is derived from the original Russian of the group's name; hence "Association for the Promotion of Skilled Trades," although literally in French this translates to "Organization Reconstruction Labor"), est. late nineteenth-century Russia, activity extended to North Africa in the I950s

OSE-Oeuvre de secours aux enfants (Organization to Save the Children)

PCF-Parti Communiste Français (French Communist Party)

PCM — before 1939, Parti Communiste du Maroc (Communist Party of Morocco); after 1943, Parti Communiste Marocain (Moroccan Communist Party) until its ban in 1960

PDI-Parti démocratique de l'Indépendance (Democratic Party for Independence)

PLS-Parti de la Libération et du Socialisme (Party of Liberation and Socialism), est. I968

PPS—Parti du Progrès et du Socialisme (Party of Progress and Socialism), est. 1974

SFIO-Section française de l'internationale ouvrière (French Section of the Workers' International)

UFM-Union des Femmes du Maroc (Union of Women in Morocco)

UGSCM-Union générale des syndicats confédérés du Maroc (General Union of Confederated Syndicates of Morocco) 
UMT—Union Marocaine du Travaille (Moroccan Labor Union)

UNEM-Union Nationale des Etudiants du Maroc (National Union of Moroccan Students), est. 1956

UNFP-Union Nationale des Forces Populaires (National Union of Popular Forces), est. 1959

WJC-World Jewish Congress 
This page intentionally left blank 
THE SULTAN'S COMMUNISTS 
This page intentionally left blank 